\title{
The Precautionary Principle in International Law
}

\subsection{Introduction}

In order to protect the environment, the precautionary approach shall be widely applied by States according to their capabilities. Where there are threats of serious or irreversible damage, lack of full scientific certainty shall not be used as a reason for postponing cost-effective measures to prevent environmental degradation. ${ }^{1}$

The previous chapter introduced seabed mineral mining as a frontier activity that is characterised by environmental risk and numerous uncertainties. The chapter concluded that in this ocean of unknowns, one thing is certain: the need to apply a precautionary approach to take early environmental management measures. This chapter explores the meaning of precaution in international law and the manner in which it can be implemented, in the context of biodiversity protection and natural resource management. This analysis provides the analytical framework for this study.

After two decades of prominence in international environmental law, the precautionary approach, or principle, needs little introduction. Before discussing the controversies and complexities surrounding precaution, it is useful to remind ourselves of its simple and logical core. It aims to ensure adequate environmental protection through the taking of early action in response to threats of environmental harm, even in the context of scientific uncertainty. Despite this practical motive, the challenge lies in articulating and assessing what the implementation of precaution entails in any given context.

Consistent with its status as a legal principle, the concept of precaution is deliberately flexible so as to encompass diverse circumstances. ${ }^{2}$ Rather than

1 Rio Declaration, principle 15.

2 Elizabeth Fisher, Judith Jones, and René von Schomberg, 'Implementing the Precautionary Principle: Perspectives And Prospects' in Elizabeth Fisher, Judith Jones, and René von Schomberg (eds), Implementing the Precautionary Principle: Perspectives And Prospects (Edward Elgar Publishing, 2006) 1-16, page 5; David Freestone, 'International Fisheries Law Since Rio: The Continued Rise of the Precautionary Principle' in Alan Boyle and David Freestone (eds), International Law and Sustainable Development: Past Achievements and Future Challenges (Oxford University Press, 2001) 135-164, page 136. 
specifying particular measures, it provides a general guide for regulatory, administrative, and judicial action in cases of risk of environmental harm. This flexibility has allowed precaution to become one of the most widely invoked principles while simultaneously blurring its parameters when attempting to formulate general definitions and implementing measures. ${ }^{3}$ Fisher et al. summarise the dilemma:

While the literature on the principle is a large one, the challenges involved in its actual and potential application have tended to be underestimated. In particular, the messy business of integrating the principle into existing institutions and relating it to well-established decisionmaking processes has not received the attention it should have. Rather, the principle has tended to be dissected in an analytical vacuum, considered from a single disciplinary perspective, or treated in a 'plug and play' manner in that its implementation is characterised as simply requiring the inclusion of the principle into policy or a legislative scheme for it to be effective. ${ }^{4}$

As Fisher et al. would have it, the crucial aspect of an analysis of the implementation of precaution must go beyond an examination of its mere articulation in legal documents to an examination of the manner in which precaution has been integrated into institutional and decision-making frameworks.

With this admonition in mind, this chapter discusses the precautionary principle with a focus on its operationalisation. Although offering a general overview of the normative aspects of precaution, the focus lies on those issues that are relevant to the context of the International Seabed Authority (ISA). To that end, the analysis highlights particularities of implementing precaution not by states, the usual focus of investigation, but by an international organisation, in respect of which at least two distinctions can be made. First, the institutional framework and decision-making process of the ISA differ from domestic governments and institutions which, as will be demonstrated in this study, affects the manner in which precaution is incorporated into the decision-making of the ISA. Second, pursuant to the 1982 United Nations Convention on the Law of the Sea (LOSC or Convention), the ISA has the unique obligation to act on behalf

3 Malgosia Fitzmaurice, Contemporary Issues in International Environmental Law (Edward Elgar Publishing, 2009), page 65.

4 Fisher, Jones, von Schomberg (n. 2), page 1. 
of humankind, ${ }^{5}$ which influences the need for public participation in the decision-making process.

The following section begins with an overview of the rationale, history, and status of precaution in international law and clarifies its relationship with the principle of prevention. Section 2.3 then defines the precautionary approach, while Section 2.4 provides an analysis of the aspects relevant to implementing precaution, which includes identifying the three levels of governance involved in its implementation. Section 2.5 concludes the chapter by identifying criteria to assess the implementation of precaution by the ISA.

\section{2}

\section{The Precautionary Principle in International Law}

\subsubsection{From Reactive to Proactive Thinking: The Rationale of Precaution}

Traditionally, international environmental law focused on remedying actual damage (reactive) or preventing identified hazards (preventive). ${ }^{6}$ Techniques to incorporate the idea of Vorsorge or foresight beyond immediate cause and effects, in other words being pre-cautious, into environmental law, were lacking. Proactive approaches to potential future harm were not part of the legal vocabulary. Instead, 'clear and convincing evidence' of environmental harm was required for instance in the Trail Smelter case. ${ }^{7}$

Emerging consciousness of the delicate nature and vulnerabilities of ecosystems, gave rise to the recognition that this evidence-first approach created several problems. First, it ignored the fact that ecosystems are inherently complex. Consequently, any prediction of the effects of human activities upon them inevitably entails uncertainty, making it difficult if not impossible to provide 'clear and convincing evidence.' Second, it did not take into account the time delay with which many harmful effects become visible in the natural environment.

The concept of precaution operates with a more proactive rationale. It calls for actions at an earlier stage, even in a time of doubt when there is not yet conclusive scientific evidence as to the harmfulness. 'Under the precautionary principle, the benefit of any such doubt is to go to the environment. In dubio

5 United Nations Convention on the Law of the Sea (adopted 10 December 1982, entered into force 16 November 1994) 1833 UNTS 3, article 137(2).

6 Jacqueline Peel, The Precautionary Principle in Practice: Environmental Decision-Making and Scientific Uncertainty (Federation Press, 2005), page 218.

7 Trail Smelter Case (US v Canada) (Arbitration Award, 16 April 1938 and 11 March 1941) 3 RIAA 1905 , page 1965 . 
pro natura: ${ }^{8}$ In addition to its legal function, precautionary thinking influences our attitude towards decision-making over environmental protection and invites us to focus on long-term environmental sustainability. ${ }^{9}$

\subsubsection{History of the Precautionary Principle}

The history and status of the precautionary approach have been extensively analysed elsewhere, ${ }^{10}$ prompting this section to provide only a core summary.

The origins of the modern day precautionary approach can be traced back to domestic environmental law in the form of scattered obligations embedding various precautionary measures. ${ }^{11}$ The first explicit reference to the principle was included in German law as the Vorsorgeprinzip in the $1970 .^{12}$ In the following decade, the principle made its debut at the international level in the context of protecting the marine environment of the North Sea from excessive pollution and waste dumping. ${ }^{13}$ Pollution had effectively been tolerated in as much as any legal action had been dependent upon a proven causal link between activity and harm. Precautionary logic meant that uncertainty was no longer a bar to action. Ehlers summarises the persuasive thinking at the time: '[a]s damage to the marine environment can be irreversible, or remediable only at considerable expense and over long periods, it is not prudent to await

8 Arie Trouwborst, "The Precautionary Principle in General International Law: Combating the Babylonian Confusion' (2007) 16 Review of European Community \& International Environmental Law 185-195, page 187.

David Freestone and Ellen Hey, 'Implementing the Precautionary Principle: Challenges and Opportunities' in David Freestone and Ellen Hey (eds), The Precautionary Principle and International Law: the Challenge of Implementation (Kluwer Law International, 1996) 249-268, page 264; Peel (n. 6), page 219.

10 Arie Trouwborst, Evolution and Status of the Precautionary Principle in International Law (Kluwer Law International, 2002), pages 7-31; David Freestone and Ellen Hey, 'Origins and Development of the Precautionary Principle' in David Freestone and Ellen Hey (eds), The Precautionary Principle and International Law: the Challenge of Implementation (Kluwer Law International, 1996) 3-15; Timothy O'Riordan and James Cameron, Interpreting the Precautionary Principle (Earthscan, 1994), part I.

11 Trouwborst (n. 10), pages 16-17.

12 James Cameron, 'The Status of the Precautionary Principle in International Law' in Timothy O'Riordan and James Cameron (eds), Interpreting the Precautionary Principle (Earthscan, 1994) 262-290, page 267; Trouwborst (n. 10), page 17.

13 Declaration on the Second International Conference on the Protection of the North Sea (London, 24-25 November 1987), articles VII, XV(ii), XVI(1); Ministerial Declaration of the Third International Conference on the Protection of the North Sea (The Hague, 8 March 1990), preamble paragraph 25; Freestone and Hey (n. 10), pages 6-7; Trouwborst (n. 10), pages $24-25$. 
proof of harmful effects before taking action.' ${ }^{14}$ The logic of precaution proved compelling and saw the principle being adopted in numerous international agreements dealing with the protection of the marine environment. ${ }^{15}$ Beyond the law of the sea, the principle also rapidly gained momentum and within a few years it was incorporated into virtually every international environmental regime, ${ }^{16}$ including on biodiversity, ${ }_{17}^{17}$ climate change, ${ }^{18}$ and biosafety. ${ }^{19}$ Its near universal acceptance was sealed with its incorporation in the 1992 Rio Declaration.

Support for such momentum came from the wider pursuit of sustainable development, which in turn was fuelled by the 1987 Brundtland Report. ${ }^{20}$ Precautionary thinking is central to achieving sustainable development and, in particular, sustainable use of the Earth's natural resources. ${ }^{21}$ It was incorporated into Agenda $21,{ }^{22}$ principle 4 of the International Law Association's New Delhi Declaration of Principles of International Law Relating to Sustainable

14 Peter Ehlers, 'The History of the International North Sea Conferences' in David Freestone and Ton Istra (eds), The North Sea: Perspectives on Regional Environmental Co-operation (Martinus Nijhoff, 1990), page 7 .

15 See for example: Convention on the Protection of the Marine Environment of the Baltic Sea (adopted 9 April 1992, entered into force 17 January 2000) 1507 UNTS 167; Convention for the Protection of the Marine Environment of the North-East Atlantic (adopted 22 September 1992, entered into force 25 March 1998) 2354 UNTs 67; Agreement for the Implementation of the Provisions of the United Nations Convention on the Law of the Sea of 10 December 1982 Relating to the Conservation and Management of Straddling Fish Stocks and Highly Migratory Fish Stocks (adopted 4 August 1995, entered into force 11 Dec 2001) 2167 UNTS 3 (FSA).

16 Freestone (n. 2), page 135; Trouwborst (n. 8), page 187.

17 Convention on Biological Diversity (adopted 5 June 1992, entered into force 29 December 1993) 1760 UnTs 79, preamble.

18 United Nations Framework Convention on Climate Change (adopted 9 May 1992, entered into force 21 March 1994) 1771 UNTS 107, article 3(3).

19 Cartagena Protocol on Biosafety to the Convention on Biological Diversity (adopted 29 January 2000, entered into force 22 September 2003) 2226 UNTS 208, preamble paragraph 4 , articles 1, 10(6), 11(8).

20 UNGA, Un Doc A/42/427 (4 August 1987).

21 See generally Nico Schrijver, The Evolution of Sustainable Development in International Law: Inception, Meaning and Status (Martinus Nijhoff, 2008) pages 184-197; Philippe Sands and Jacqueline Peel, Principles of International Environmental Law (Cambridge University Press, 3rd ed, 2012), pages 219-220. 
Development, ${ }^{23}$ the Johannesburg Plan of Implementation, ${ }^{24}$ and the Rio+20 outcome document. ${ }^{25}$

Nonetheless, the precautionary principle did not escape criticism. ${ }^{26}$ Some commentators dismiss the principle for being too vague ${ }^{27}$ or criticise it for lacking normative content regarding the desired level of protection. ${ }^{28}$ However, criticising precaution because it results in diverse outcomes in different contexts fails to consider the inherently flexible nature of a legal principle. Fisher poignantly calls this simplistic approach 'precaution spotting':

[...] 'precaution spotting' has been based on the assumption that the principle is an autonomous transplantable rule. On this basis, the variations in how it is formulated, interpreted, and implemented suggest that the principle is either incoherent or lacking legal content. This characterization, however, is at odds with the fact that the principle is a flexible legal principle shaped by the surrounding legal culture. [...] Variation is thus due to different legal cultures, legal issues, and disagreements about those legal issues. ${ }^{29}$

As discussed in Section 2.3 below, this flexibility is essential to, and indeed a strength of, the precautionary principle.

Other critics, such as Sunstein argue that the principle can create paralysis, since it requires action whenever there is a risk of harm. Sunstein argues that although precaution demands regulation of risk, it actually hinders that regulation because precautionary action or inaction may, in turn, carry risks itself

23 Nico Schrijver, 'ILA New Delhi Declaration of Principles of International Law Relating to Sustainable Development' (2002) 49 Netherlands International Law Review 299-305.

24 Plan of Implementation of the World Summit on Sustainable Development, A/CONF.199/20 (4 September 2002), paragraphs 23, 109 (f).

25 UNGA, UN Doc A/Res/66/288 (27 July 2012), paragraph 158.

26 For discussions on the main criticism of the precautionary principle and their counter-arguments, see Per Sandin et al., 'Five Charges against the Precautionary Principle' (2002) 5 Journal of Risk Research 287-299; Alessandra Arcuri, 'Reconstructing Precaution, Deconstructing Misconceptions' (2007) 21 Ethics \& International Affairs 359-379.

27 Daniel Bodansky, 'Scientific Uncertainty and the Precautionary Principle' (1991) 33 Environment, 4-5, 34-44.

28 Bénédicte Sage-Fuller, The Precautionary Principle in Marine Environmental Law: With Special Reference to High Risk Vessels (Routledge, 2013).

29 Elizabeth Fisher, 'Precaution, Precaution Everywhere: Developing a "Common Understanding” of the Precautionary Principle in the European Community' (2002) 9 Maastricht Journal of European and Comparative Law 7-28, page 8. 
which ought to be avoided. ${ }^{30}$ According to Arcuri, however, this criticism is based on a 'radical and misconceived definition of the principle' that ignores the precautionary thresholds which ensure that precaution does not apply to every imaginable, small risk. ${ }^{31}$ These thresholds are examined below in Section 2.3.4.

These criticism, have not, however, prevented the integration of the precautionary principle into modern environmental law, not least because, as Gullett notes, the principle is based on 'an uncontroversial espousal of commonsense. 32 The rapid rise of the principle of precaution has naturally prompted high expectations for its influence on decision-making. However, as with any rapidly developing concept, working out the details of its application can take significantly longer than the initial acceptance of the idea behind it. As Freestone highlighted at the turn of the century, the emergence of the precautionary principle was 'one of the most remarkable developments of the last decade.' Now, 'the issue for the next century is the extent to which the rhetoric of the principle can be operationalized. 33

\subsubsection{Status of the Precautionary Principle in International Law}

Given the rapid rise of precaution, the question as to its possible customary international law status has inevitably arisen. ${ }^{34}$ Trouwborst's extensive study, published in 2002, found that the core content of the principle had attained the status of a general principle of international environmental law and a customary norm. ${ }^{35}$ Numerous scholars broadly concur with the finding of precaution having reached customary status ${ }^{36}$ although some controversy

30 Cass R. Sunstein, Laws of Fear: Beyond the Precautionary Principle (Cambridge University Press, 2005), pages 26-34; William J. Mckinney and H. Hammer Hill, 'Of Sustainability and Precaution : The Logical, Epistemological, and Moral Problems of the Precautionary Principle and Their Implications for Sustainable Development' (2000) 5 Ethics and the Environment 77-87, page 79 .

$31 \quad$ Arcuri (n. 26), pages $365^{-3} 36$.

32 Warwick Gullett, 'Environmental Protection and the Precautionary Principle: A Response to Scientific Uncertainty in Environmental Management' (1997) 14 Environmental and Planning Law Journal 52-69, page 52.

33 Freestone (n. 2), page 135 .

34 Daniel Bodansky, 'New Developments in International Environmental Law: Remarks' (1991) 85 Proceedings of the Annual Meeting (American Society of International Law) 413417, page 413 .

35 Trouwborst (n. 10).

36 Sands and Peel (n. 21), page 228; James Cameron and Juli Abouchar, 'The Status of the Precautionary Principle in International Law' in David Freestone and Ellen Hey (eds), 
remains. ${ }^{37}$ Support for the principle by international judicial bodies remains sporadic though it is increasing. For example, in the Pulp Mills case Judge Ad Hoc Vinuesa unambiguously stated: ' $t$ ] he precautionary principle is not an abstraction or an academic component of desirable soft law, but a rule of law within general international law as it stands today.' 38 The International Tribunal for the Law of the Sea (ITLOS), in the Bluefin Tuna cases, held that 'the parties should in the circumstances act with prudence and caution to ensure that effective conservation measures are taken to prevent serious harm to the stock of southern bluefin tuna. ${ }^{39}$ Despite this implicit endorsement of the precautionary approach, the Tribunal refrained from confirming a customary the status of precaution. ${ }^{40}$ This changed in 2011, when the Seabed Disputes Chamber expressly found a 'trend' towards the precautionary approach becoming customary law. ${ }^{41}$ Although this is still no conclusive statement as to the customary nature of precaution, it provides the latest confirmation of the central importance of precaution, especially in the marine context. For the purpose of this study, the applicability of the precautionary principle is taken as beyond doubt, not least because the principle is specifically incorporated into the International Seabed Authority's Mining Code. ${ }^{42}$ Instead of dwelling on the

The Precautionary Principle and International Law: the Challenge of Implementation (Kluwer Law International, 1996) 29-52, pages 30-31; Nicolas De Sadeleer, Environmental Principles: From Political Slogans to Legal Rules (Oxford University Press, 2002), pages 92, 100, 318-319; Freestone (n. 2), page 137; Alex G. Oude Elferink, 'Governance Principles for Areas beyond National Jurisdiction' (2012) 27 The International Journal of Marine and Coastal Law 205-259, pages 226-227; Owen McIntyre and Thomas Mosedale, "The Precautionary Principle as a Norm of Customary International Law' (1997) 9 Journal of Environmental Law 221-241, pages 222-223, 241.

37 Ole W. Pedersen, 'From Abundance to Indeterminacy: The Precautionary Principle and Its Two Camps of Custom' (2014) 3 Transnational Environmental Law 323-339.

38 Case Concerning the Pulp Mills on the River Uruguay (Argentina $v$ Uruguay) (Provisional Measures) [2006] ICJ Rep 113, page $15^{2}$ (Judge Ad Hoc Vinuesa).

39 Southern Bluefin Tuna Cases (New Zealand v Japan; Australia v Japan) (Provisional Measures) (ITLOs Cases No. 3 \& 4, 27 August 1999), paragraph 77; See also The MOX Plant Case (Ireland v UK) (Provisional Measures) (ITLos Case No.10, 3 December 2001), paragraph 84.

$40 \quad$ Southern Bluefin Tuna Cases (n. 39), paragraph 9 (Judge Treves) and paragraph 16 (Judge Laing).

41 Responsibilities and Obligations of States Sponsoring Persons and Entities with Respect to Activities in the Area (Advisory Opinion) (Seabed Disputes Chamber, Case No. 17, 1 February 2011) (SDC Advisory Opinion), paragraph 135. 
legal status, the focus here is on the way forward, 'the circumstances in which the precautionary principle is applied and variations in its implementation. ${ }^{43}$

\subsubsection{Overlapping Principles: Precaution and Prevention}

Completing the introductory discussion on precaution requires a brief look at the link between the precautionary principle and the preventive principle. Both principles share a common aim: to prevent environmental harm, albeit with different philosophical underpinnings. A common, yet oversimplified, distinction asserts that prevention seeks to avert known or foreseeable harm, whereas precaution requires such action at an earlier stage, even where potential effects remain uncertain, ${ }^{44}$ provided the threshold for gravity and likelihood of harm are met. This alludes to two interlinked factors that distinguish prevention and precaution: timing and uncertainty.

First, international law has long required preventive action once damage has been determined. The precautionary approach seeks to shift the focus to an earlier point in time, even though there might still be uncertainties as to the potential harm. "The new element is that of timing, rather than the need for, remedial action. ${ }^{45}$ However, there is no reason to believe that precaution finishes at a particular point on the time scale, as long as the thresholds for harm are met. To assume that precaution only applies up to the point in time after which prevention takes over is an oversimplification as it rests on (a) a purely abstract distinction based on uncertainty, and (b) a misinterpretation of the role of uncertainty. This leads to the second commonly drawn distinction.

Second, the presence of scientific uncertainty is often cited as the difference between precaution and prevention. ${ }^{46}$ However, this distinction is purely abstract. Not only is the idea of scientific certainty a myth, ${ }^{47}$ but any sharp

$43 \quad$ Fitzmaurice (n. 3), page 6.

44 Trouwborst (n. 10), pages $3{ }^{6}-37$; Nigel Haigh, 'The Introduction of the Precautionary Principle in the UK' in Tim O'Riordan and James R. Cameron (eds), Interpreting the Precautionary Principle (Earthscan, 1994) 229-251, 241; De Sadeleer (n. 36), page 222.

45 Freestone and Hey (n. 10) page 13.

46 Nicolas De Sadeleer, 'The Principles of Prevention and Precaution in International Law: Two Heads of the Same Coin?' in Malgosia Fitzmaurice and others (eds), Research Handbook on International Environmental Law (Edward Elgar Publishing, 2010) 182-199, page 186.

47 Nichollsv Director-General of National Parks and Wildlife (1994) 84 LGERA 397, 419; William R. Freudenburg, Robert Gramling, and Debra J. Davidson, 'Scientific Certainty Argumentation Methods (SCAMs): Science and the Politics of Doubt*' (2008) 78 Sociological Inquiry 2-38; Mark Monaghan, Ray Pawson, and Kate Wicker, 'The Precautionary Principle and Evidence-Based Policy' (2012) 8 Evidence \& Policy 171-191, page 185. 
distinction between prevention and precaution is hardly operable in practice. 48 Prevention, which seeks to address quantifiable or 'known' risks, still embodies a degree of uncertainty. 'Uncertainty is obviously inherent in the very notion of risk. ${ }^{49}$ As such, all measures to address risks include precautionary elements. ${ }^{50}$ In the words of Haigh: 'Since there is likely to be uncertainty about when uncertainty disappears there will also be uncertainty about whether to talk of the principle of precaution rather than of prevention. ${ }^{51}$

Moreover, as Trouwborst notes, precaution applies not because of uncertainty, but in spite of it. To remind ourselves, Principle 15 of the Rio Declaration reads: 'Where there are threats of serious or irreversible damage, lack of full scientific certainty shall not be used as a reason for postponing cost-effective measures to prevent environmental degradation.' In other words, protective actions should not be impeded by uncertainty. The trigger for precaution is the concern over environmental harm, not uncertainty itself. ${ }^{52}$

Here, it is also worth noting an easy misperception, namely that prevention relies on science whereas precaution does not. ${ }^{53}$ This is not true. Scientific considerations lie at the heart of the precautionary principle as it relies on an in-depth assessment of scientific knowledge, ${ }^{54}$ including any remaining uncertainties..$^{55}$ Similarly, as discussed in Section 2.4, furthering scientific research is an integral part of the precautionary approach.

48 Harald Hohmann, Precautionary Legal Duties and Principles of Modern International Environmental Law: The Precautionary Principle: International Environmental Law Between Exploitation and Protection (Graham \& Trotman, 1994), page 334.

49 Arie Trouwborst, 'Prevention, Precaution, Logic and Law: The Relationship between the Precautionary Principle and the Preventative Principle in International Law and Associated Questions' (2009) 2 Erasmus Law Review 105-127, page 118.

50 Ibid.

$5^{1} \quad$ Haigh (n. 44), page 241.

$5^{2}$ For a detailed discussion including a survey of the various formulations of precaution, see Arie Trouwborst, Precautionary Rights and Duties of States (Martinus Nijhoff, 2006), pages 91-96.

53 For a detailed discussion of this criticism see De Sadeleer (n. 36), pages 174-180.

54 Laurence David Mee, 'Scientific Methods and the Precautionary Principle' in David Freestone and Ellen Hey (eds), The Precautionary Principle and International Law: the Challenge of Implementation (Kluwer Law International, 1996) 109-131, pages 127-131; John S. Gray, 'Integrating Precautionary Scientific Methods into Decision-Making' in David Freestone and Ellen Hey (eds), The Precautionary Principle and International Law: the Challenge of Implementation (Kluwer Law International, 1996) 133-146, pages 143-146.

55 De Sadeleer (n. 36), pages 174-180; Commission of the European Communities, Communication from the Commission on the precautionary principle, (2 February 2000), page 12. 
In conclusion, the distinction between precaution and prevention is blurry at best. It is clear that precaution starts to apply at an earlier stage and that some degree of uncertainty is characteristic of both concepts. For this reason, Trouwborst argues that the precautionary principle has 'absorbed' the preventive principle. ${ }^{56}$

In any event, to bring this abstract discussion back to the topic at hand: it is submitted that seabed mining falls squarely within the category of activities requiring the implementation of precaution. As discussed in Chapter 1, seabed mining carries risks of serious environmental harm and involves high degrees of uncertainty. These include the severity and spatial extent of harm, recovery rates, and cumulative impacts. ${ }^{57}$ Thus, the question is not whether precaution applies but how it can be implemented.

\subsection{Defining the Precautionary Principle: Three Elements}

It order to assess its implementation, it is first necessary to define what the precautionary principle entails. The rich literature on precaution offers numerous descriptions in that regard. The most structured and comprehensive analysis is provided by Trouwborst, who illustrates precaution by way of a tripod with the legs being the three widely agreed components of (a) threat of environmental harm, (b) uncertainty, and (c) action. ${ }^{58}$

\subsubsection{Threat of Environmental Harm}

The presence of a threat of environmental harm is the very reason behind the development of the precautionary approach and thus a crucial element of it. However, in order to exclude instances of minor concern, the threat has to reach a certain threshold before the precautionary approach is triggered.59 Thus, it is closely linked to the concept of risk, ${ }^{60}$ which can be described as the product of the probability of a certain harm arising, times the gravity of such harm. In short:

\footnotetext{
56 Trouwborst (n. 49).

57 See Chapter 1.2.2.

$5^{8}$ Trouwborst (n. 52), pages 21-35; see also Stephen M. Gardiner, 'A Core Precautionary Principle' (2006) 14 Journal of Political Philosophy 33-6o; Cameron and Abouchar (n. 36), page 45 .

59 Trouwborst (n. 52), pages 43-44, 66-67.

6o Commission of the European Communities (n. 55), page 12.
} 
Risk $=$ gravity $\times$ probability of harm ${ }^{61}$

Both components are relevant for analysing the precautionary elements of (a) threat and (b) uncertainty, and they are mirrored in the various formulations of the precautionary approach.

As for the gravity of harm, a substantial number of international instruments omit any specific threshold. ${ }^{62}$ Yet, a minimum threshold may nevertheless be implied, to prevent the precautionary approach from being invoked for unavoidable, minor, or every-day impacts we humans inevitably have on our natural environment. ${ }^{63}$ Other common formulations require significant or serious or irreversible damage. ${ }^{64}$ The latter obviously sets the bar for triggering precaution higher. Importantly, whether a risk is classified as significant or serious depends on the site in question as well as on societal values, as discussed in Section 2.4.2. ${ }^{65}$ As the European Court of Justice highlighted in relation to applying precaution to cockle fishing in the Wadden Sea: 'in assessing the potential effects of a plan or project, their significance must be established in the light, inter alia, of the characteristics and specific environmental conditions of the site concerned by that plan or project.' ${ }^{66}$

The probability of harm is also subject to a minimum threshold, which is best explained in connection with the element of uncertainty.

\subsubsection{Uncertainty}

Despite the precautionary approach applying even in cases of scientific uncertainty, not all levels of uncertainty are covered. As with gravity of harm, there has to be a minimum probability of harm occurring, something more than hypothetical, as precaution would otherwise apply to every imaginary threat. In other words, there is a maximum limit on the level of uncertainty. However, as noted above, there is no minimum level of uncertainty required for precaution to apply.

61 Trouwborst (n. 52), pages 26-29; Aaron Wildavsky, 'Trial and Error Versus Trial Without Error' in Julian Morris (ed), Rethinking Risk and the Precautionary Principle (ButterworthHeinemann, 2000) 22-45, page 25 .

62 Trouwborst (n. $\left.5^{2}\right)$, pages $45^{-47}$.

63 Ibid., pages $47-48$.

64 Ibid., pages $44-67$.

65 Ibid., pages $133-136$.

66 Landelijke Vereniging tot Behoud van de Waddenzee and Nederlandse Vereniging tot Bescherming van Vogels $v$ Staatssecretaris van Landbouw, Natuurbeheer en Visserij (C-127/02) [2004] ECR I-7405, paragraph 48. 
The threshold for the probability of harm varies across international instruments, with some merely requiring the possibility that harm might, may, or could occur. ${ }^{67}$ Similarly, 'a large number of definitions in the legal instruments' merely require threats for the precautionary approach to apply. ${ }^{68}$ In his comprehensive analysis, Trouwborst found that under customary law there must be at least 'reasonable grounds for concern' that environmental harm may occur, that is more than a theoretical possibility but 'less than proof of probability of harm.' 69

It should be highlighted that while uncertainty is subject to a maximum threshold, the precautionary principle encompasses all types of uncertainty. This includes epistemic and ontological uncertainties, ${ }^{70}$ meaning uncertainties inherent in studying complex systems. ${ }^{71}$ It also includes the entire spectrum of situations from quantifiable risk to ignorance, in which neither gravity nor probability are quantifiable. ${ }^{72}$

\subsubsection{Remedial Action}

The third, and most crucial, element of precaution is that of remedial action at an early stage. Once the thresholds for gravity and probability of an environmental threat are crossed, the precautionary approach requires 'measures to prevent environmental degradation. ${ }^{73}$ Without it precaution would be meaningless. Yet, this is precisely where the challenge lies. Which measures are necessary? How can the rhetoric of precaution be operationalised? Before exploring this question in detail in Section 2.4, two general criteria must be highlighted.

\subsubsection{Effectiveness}

Any precautionary measure must first and foremost be effective, meaning it has to be capable of achieving the desired level of protection. ${ }^{74}$ Comparing

67 Trouwborst (n. $\left.5^{2}\right)$, pages 99-100.

68 Ibid., pages $105^{-106 .}$

69 Ibid., pages 118-119.

70 Chapter 2.4.4; Rosie Cooney, 'A Long and Winding Road? Precaution from Principle to Practice in Biodiversity Conservation' in Elizabeth Fisher, Judith Jones, and René von Schomberg (eds), Implementing the Precautionary Principle: Perspectives And Prospects (Edward Elgar Publishing, 2006) 223-244, page 229; Trouwborst (n. 52), pages 72-82. W.E. Walker et al., 'Defining Uncertainty: A Conceptual Basis for Uncertainty Management in Model-Based Decision Support' (2003) 4 Integrated Assessment 5-17, pages 13-14.

72 De Sadeleer (n. 46), page 191. Trouwborst (n. 52), pages 86-89.

73 Rio Declaration, principle 15.

74 Commission of the European Communities (n. 55), page 17. 
measures requires examining both costs and benefits of various (in)actions and includes considering both short-term and long-term effects. ${ }^{75}$ The aim is to create measures that are specific enough to be clear and meaningful, yet flexible enough to allow for changes if and when new information becomes available. ${ }^{76}$ Additionally, consistency in precautionary measures, as promoted for example at European Union level, can provide a degree of certainty and planning reliability for stakeholders. ${ }^{77}$

Assessing the effectiveness of a measure requires, first, the determination of the desired level of protection. This will be different in each scenario to which precaution applies. This sectoral variability is what Sage-Fuller regards as a deficiency of the precautionary principle. She argues that without normative value regarding what should be protected and the desired level of protection, the precautionary principle fails to provide guidance about the measures to be taken in applying the principle. ${ }^{78}$ This in turn, she argues, prevents the principle from reaching customary international law status. However, Sage-Fuller recognises that the precautionary principle can have normative value within a sectoral context, where the desired level of protection has been agreed on. ${ }^{79}$

While it is true that the normative consideration as to what should be protected will differ in each context, this is a necessity in order for the principle to respond to the complexities of risk management. ${ }^{80}$ This flexibility allows precaution to take into account the characteristics of different ecosystems.

Nonetheless, precaution requires active consideration of the desired level of protection in each context. For example, in some fisheries contexts the conser-

75 Ibid., page 18; Rosie Cooney and Barney Dickson, 'Precautionary Principle, Precautionary Practice: Lessons and Insights' in Rosie Cooney and Barney Dickson (eds), Biodiversity and the Precautionary Principle: Risk, Uncertainty and Practice in Conservation and Sustainable Use (Earthscan, 2005) 287-298, page 295; Jorge Rabinovich, 'Parrots, Precaution and Project Ele: Management in the Face of Multiple Uncertainties' in Rosie Cooney and Barney Dickson, op. cit., 173-188.

76 Rosie Cooney and Barney Dickson, 'Appendix: Guidelines for Applying the Precautionary Principle to Biodiversity Conservation and Natural Resource Management' in Rosie Cooney and Barney Dickson (eds), Biodiversity and the Precautionary Principle: Risk, Uncertainty and Practice in Conservation and Sustainable Use (Earthscan, 2005) 299-306, page 301.

77 Commission of the European Communities (n. 55), page 18.

78 Sage-Fuller (n. 28), page 117 .

79 Ibid., pages $215^{-216 .}$

8o Aline Jaeckel, 'Book Review: The Precautionary Principle in Marine Environment LawWith Special Reference to High Risk Vessels, Written by Bénédicte Sage-Fuller' (2015) 30 The International Journal of Marine and Coastal Law 215-219. 
vation benchmark, although not without criticism, ${ }^{81}$ is to 'maintain or restore stocks at levels capable of producing maximum sustainable yield. ${ }^{82}$ But what is the agreed level of environmental protection with respect to deep seabed mining? As discussed in Chapters 5.4.6 and 7.2, a specific conservation benchmark has yet to be agreed, which creates a range of challenges for the implementation of the precautionary approach.

\subsubsection{Proportionality}

The second criterion is that while precautionary measures have to be effective, they should not be more restrictive than necessary. In other words, the measures have to be proportional to the desired level of protection. ${ }^{83}$ Proportionality is directly related to the gravity and probability of harm ${ }^{84}$ and requires a case-by-case assessment.

Assessing the proportionality of measures requires considerations of both short and long-term effects, which may include taking into account any potential impacts affecting future generations, especially in relation to harm to ecosystems. ${ }^{85}$ The European Commission further stresses that 'one should also consider replacing the product or procedure concerned by safer products or procedures. ${ }^{86}$ For seabed mining, such a comprehensive approach includes considering alternative means of meeting the demand for minerals, as explored in Chapter 7.2.1.

Both the proportionality and the effectiveness of precautionary measures will depend on whether the potential harm is reversible. Fisheries, for example, do not cause environmental damage per se; rather, it is the scale of modern fisheries that creates harm. The impacts of fisheries are, in most cases, reversible. As such, the precautionary approach to fisheries is about determining 'the

81 Daniel D. Huppert, 'Risk Assessment, Economics, and Precautionary Fishery Management' in Precautionary Approach to Fisheries Part 2: Scientific Papers (FAO Fisheries Technical Paper 350/2, 1995).

$82 \quad$ FSA, article $5(\mathrm{~b})$.

83 Simon Marr, The Precautionary Principle in the Law of the Sea:Modern Decision-making in International Law (Martinus Nijhoff, 2003), pages 35-37; Ronnie Harding and Elizabeth Fisher, 'Introducing the Precautionary Principle' in Ronnie Harding and Elizabeth Fisher (eds), Perspectives on the Precautionary Principle (Federation Press, 1999) 2-25, page 12.

84 See the illustrations in Trouwborst (n. 52), pages 153-155.

85 Commission of the European Communities (n. 55), pages 17-18.

86 Ibid. 
quantities of fish that can be removed without damaging the system's productivity', which 'can be determined with some accuracy.' 87

In line with this objective, the United Nations Fish Stocks Agreement sets out specific precautionary standards. For example, Article 6(3)(b) of the Agreement requires states parties to determine 'stock-specific reference points and the action to be taken if they are exceeded.' These must include both conservation reference points, that is 'boundaries which are intended to constrain harvesting within safe biological limits within which the stocks can produce maximum sustainable yield', and target reference points, which are intended to meet management objectives. ${ }^{88}$

In contrast, chemical pollution, the context in which the precautionary principle was first accepted in international law, ${ }^{89}$ differs from fisheries in that its impact may not always be reversible. As discussed in Chapter 1.2.2, seabed mining may fall into both categories. The precautionary standards to be adopted by the International Seabed Authority must reflect this. The Seabed Disputes Chamber provided valuable guidance on the proportionality of environmental measures, in the context of the due diligence obligation of states sponsoring mining operations under the ISA regime:

"Due diligence" is a variable concept. It may change over time as measures considered sufficiently diligent at a certain moment may become not diligent enough in light, for instance, of new scientific or technological knowledge. It may also change in relation to the risks involved in the activity. As regards activities in the Area, it seems reasonable to state that prospecting is, generally speaking, less risky than exploration activities which, in turn, entail less risk than exploitation. Moreover, activities in the Area concerning different kinds of minerals, for example, polymetallic nodules on the one hand and polymetallic sulphides or cobalt rich ferromanganese crusts on the other, may require different standards of

87 Serge M. Garcia, 'The Precautionary Approach to Fisheries and Its Implication for Fishery Research, Technology and Management: An Updated Review' in Precautionary Approach to Fisheries Part 2: Scientific Papers (FAO Fisheries Technical Paper 350/2, 1996).

88 FSA, annex II paragraph 2. For a discussion of the relevant provisions of the FSA, see David Freestone, 'Implementing Precaution Cautiously: The Precautionary Approach in the Straddling and Highly Migratory Fish Stocks Agreement' in Ellen Hey (ed), Developments in International Fisheries Law (Kluwer Law International, 1999) 287-325, pages 313-322.

89 Chapter 2.2.2. 
diligence. The standard of due diligence has to be more severe for the riskier activities. ${ }^{90}$

Similarly, which precautionary measure is proportionate depends to the situation and has to be determined on a case-by-case basis.

\subsubsection{The Role of Thresholds}

As this section has discussed, the precautionary principle is subject to gravity and probability thresholds, designed to prevent precaution from becoming excessively wide in scope which would render it unworkable. Moreover, these thresholds are relevant to determining the proportionality of precautionary measures. Nonetheless, understanding thresholds as an "all-or-nothing" trigger of precaution can be problematic in that it may be difficult to determine clearly the probability and gravity of harm in the face of uncertainty. Thresholds may in theory present an 'escape clause' from precautionary obligations ${ }^{91}$ in cases where their usage may be very much warranted. Thus, it is important to examine fully any uncertainties in the decision-making process. After all, the core of the precautionary approach is to not postpone protective measures despite remaining scientific uncertainties. Rather, the criteria of effectiveness and proportionality are to guide the choice of measures. As Trouwborst reminds us: 'In case of doubt as to whether particular measures are actually suitable for this purpose, it is in conformity with the precautionary principle to err on the side of caution. 92

\subsection{Implementing the Precautionary Principle}

\subsubsection{The Three Dimensions of Implementing Precaution}

Despite its general acceptance, confusion remains as to how to give practical effect to the precautionary principle. In the law of the sea context precaution is marked by implementation gaps. ${ }^{93}$ Overall, the principle is often said to have

9o SDC Advisory Opinion, paragraph 117.

91 Warwick Gullett, "The Threshold Test of the Precautionary Principle in Australian Courts and Tribunals: Lessons for Judicial Review' in Elizabeth Charlotte Fisher and others (eds), Implementing the Precautionary Principle: Perspectives And Prospects (Edward Elgar, 2006) 182-200; Trouwborst (n. 52), page 44.

92 Trouwborst (n. $\left.5^{2}\right)$, page 149.

93 BBNJ Working Group, UN Doc A/61/65 (20 March 2006), annex I paragraph 33; Kristina M. Gjerde et al., 'Current Legal Developments—IUCN Workshop on High Seas Governance 
had a rather modest success. ${ }^{94}$ This may be partly due to the fact that it has caused widely different expectations, which inevitably leads to disappointments. While some may view precaution as a revolutionary tool, others regard it as far more limited. This section examines the various interpretations of how precaution can be implemented and identifies three dimensions involved in its implementation: institutional and procedural dimensions, as well as the taking of protective measures.

\subsubsection{Institutional Dimension}

Implementing precaution includes an institutional dimension. This stems from the fact that the decision over which precautionary measures to take and how to arrive at that decision will be determined by existing bodies. They, in turn, require the institutional capacity and competencies to provide for precautionary decision-making, adopt protective measures, and ensure their monitoring and enforcement. As Fisher and Harding point out, 'an overwhelming influence on what is understood to be the implications of the precautionary principle for decision-making will be its institutional context', that is mainly public administration. ${ }^{95}$ Institutional measures might include allowing 'a privileged role for scientific information, perhaps by the establishment of a scientific and technical advisory committee or the like ${ }^{96}$ but also the capacity to enforce protective measures and amend existing measures if new knowledge is acquired. ${ }^{97}$

\subsubsection{Procedural Dimension}

Several commentators focus on how precaution can be implemented through procedural means. Importantly, however, the word procedural is used to refer to different precautionary measures. Freestone and Hey highlight procedural measures to include reversing the burden of proof, ${ }^{98}$ listing harmless activities, ${ }^{99}$ or adjusting voting procedures to prevent decisions over protective measures

for the 21st Century' (2008) 23 The International Journal of Marine and Coastal Law 359363 , page 361 .

94 Fitzmaurice (n. 3); Gullett (n. 32).

95 Elizabeth Fisher and Ronnie Harding, 'The Precautionary Principle and Administrative Constitutionalism: The Development of Frameworks for Applying the Precautionary Principle' in Elizabeth Fisher, Judith S. Jones, and René von Schomberg (eds), Implementing the Precautionary Principle: Perspectives And Prospects (Edward Elgar Publishing, 2006)

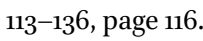

$96 \quad$ Freestone and Hey (n. 9), page 264.

97 Chapters 7.3, 8.2.

$98 \quad$ Ibid., page 259 .

99 Ibid., page 265. 
to be slowed down unnecessarily. ${ }^{100}$ Additionally, De Sadeleer highlights risk assessment procedures, including environmental impact assessments and monitoring of activities. ${ }^{101}$

Peel on the other hand argues that precaution may be an exclusively procedural principle, ${ }^{102}$ which requires three measures: (1) critically assessing uncertainties in scientific information, (2) ensuring transparency in balancing competing interests, and (3) potentially broadening participation in the decision-making process. ${ }^{103}$ Fisher advocates a similarly narrow focus on procedure and highlights that the success or failure of the implementation of precaution 'will depend on how adequately and meaningfully scientific uncertainty is taken into account in the decision-making process and not upon whether preventive action was taken.'104

The precautionary approach applies to a wealth of circumstances and issues. Peel observes that what all contexts have in common is an element of uncertainty. She argues that 'an implementation approach that concentrates on how the process accommodates uncertainty will be capable of wide and flexible application in the differing factual circumstances that confront decision-makers.' 105 The advantage of such a narrow, procedural interpretation is twofold. First, it overcomes the problems associated with understanding the thresholds of harm as an all-or-nothing trigger for precautionary action ${ }^{106}$ by diverting the focus onto procedural aspects, which by definition are more nuanced. ${ }^{107}$ Second, it may prevent the hypothetical situation in which the need for precautionary measures to be cost-effective and proportional may render the principle ineffective. ${ }^{108}$

Although procedural measures are undoubtedly part and parcel of a successful implementation of precaution, reducing the principle to this dimension is problematic for several reasons. First, exclusively focusing on uncertainties at the implementation stage rests on a misinterpretation of the role of uncertainty. As pointed out above, precaution applies 'in spite

\footnotetext{
100 Ibid., pages 264-265.

101 De Sadeleer (n. 36), pages 202-211.

102 Peel (n. 6), pages 149, 158-159.

103 Ibid., pages 156-157.

104 E. Fisher, 'Precaution, Law and Principles of Good Administration' (January 2005) $5^{2}$ Water Science and Technology 19-24, page 19; see also Peel (n. 6), page 228.

105 Peel (n. 6), page 220.

106 Chapter 2.3.4.

107 Peel (n. 6), page 221.

108 Fitzmaurice (n. 3), page 63 .
} 
of uncertainty, not because of it.'109 It would be absurd to suggest that protective measures become redundant if uncertainties are reduced and environmental harm becomes more certain. Instead, the more stable common feature across all situations where precaution will be applied is a concern over environmental or other harm.

Second, one might say that articulating and assessing uncertainties are prerequisites for applying precaution, in so much as they are necessary to identify the probability and gravity of harm, namely the triggers for the precautionary approach. Once a threat of environmental harm has been established, the question turns to which precautionary action to take. It is true that highlighting and critically examining the uncertainties at hand would, in many situations, already go a long way towards applying precaution. However, that is not to say that implementing precaution can be reduced to these exercises. Principle 15 of the Rio Declaration unambiguously requires 'measures to prevent environmental degradation.' Phrasing it in the negative, Judge Ad Hoc Charlesworth, in her separate opinion, describes precaution as entailing 'the avoidance of activities that may threaten the environment even in the face of scientific uncertainty $[\ldots]$..110

This leads to the third, and most crucial reason, namely that an exclusive focus on how a decision is reached, and ignoring which decision is ultimately taken, may lead to perverse outcomes. The fundamental aim of precaution is to prevent environmental damage. As Gardiner points out, a purely procedural interpretation of the precautionary principle 'offers us no reason to believe that they will actually do anything to protect the environment.'111 He provocatively states: 'the destruction of the earth ought not to be the necessary result of applying the precautionary principle. 112 Yet a purely procedural reading of precaution could, in principle, allow just that.

As such, it, fourth, disregards the fundamental criterion of effectiveness. As discussed in Section 2.3.3 above, any precautionary measure must selfevidently be effective in contributing to meet the desired level of environmental protection. Fifth and finally, it disregards protective measures that have been taken specifically to give effect to the precautionary approach.

\footnotetext{
109 Trouwborst (n. 8), page 191; Chapter 2.2.4.

110 Whaling in the Antarctic (Australia v Japan: New Zealand intervening) (Judgment) (ICJ, $3^{1}$ March 2014) (Separate Opinion of Judge Ad Hoc Charlesworth), paragraph 6.

111 Gardiner (n. 58), page 42.

112 Ibid., page 43 .
} 


\subsubsection{Protective Measures}

As has become clear, the spectrum of precautionary measures also incorporates the most obvious category of measures, those that are in themselves protecting the environment. ${ }^{113}$ After all, it is sometimes referred to as the 'principle of precautionary action.' 114 Precaution must be translated into 'concrete policy and management measures that are readily understood, that address the conservation problem and that identify actions to be taken in specific contexts. Without these, incorporation of the Principle in law or policy may have little influence on practice.'115 For the purpose of this study, these measures will be termed 'protective measures', as they directly safeguard against environmental harm.

Common examples of protective measures include banning certain activities or substances, ${ }^{116}$ establishing safety margins, ${ }^{117}$ and using the best available technology, ${ }^{118}$ but also include scientific and economic research to enhance knowledge of long-term options. ${ }^{119}$ The list is non-exhaustive since what are appropriate measures will differ in each context. ${ }^{120}$

It would be difficult to argue that deploying these measures is not formally part of implementing the precautionary approach, although not every measure will be appropriate in all circumstances. Determining suitable measures requires considering the situation at large including possible counter-effects that protective measures might trigger. ${ }^{121}$ The goal, after all, is to find measures that are effective in reaching the conservation objective but also proportionate to it.

113 Commission of the European Communities (n. 55), pages 15-20; Cooney (n. 70), pages 232-233; Cameron and Abouchar (n. 36), pages 50-51.

114 Ulrich Beyerlin and Thilo Marauhn, International Environmental Law (Hart Publishing, 2011), pages 47, 54; Ellen Hey, 'The Precautionary Concept in Environmental Policy and Law: Institutionalizing Caution' (1992) 4 Georgetown International Environmental Law Review 303-318, page 304 .

115 Cooney and Dickson (n. 76), page 301.

116 Freestone and Hey (n. 9); Trouwborst (n. 52), pages 165-169; Rosie Cooney, The Precautionary Principle in Biodiversity Conservation and Natural Resource Management: An Issue Paper for Policy-Makers, Researchers and Practitioners (IUCN, 2004), page 30.

117 Cooney (n. 116), page 30; Trouwborst (n. 52), pages 169-170.

118 Trouwborst (n. 52), pages 172-174.

119 Hey (n. 114), page 311; Trouwborst (n. 52), pages 174-177.

120 Trouwborst (n. 52), pages 179-191.

121 Cooney (n. 70), pages 231-233. 
A Three-dimensional Assessment of the Implementation of Precaution

As has been shown, there remains some confusion over how to implement the precautionary approach. ${ }^{122}$ Various measures have been identified and numerous more exist. It is helpful to recall that, by nature of being a legal principle (not a rule) covering widely different situations, the precautionary approach does not provide a mathematical formula for which measures to deploy in order to operationalise the abstract concept. In fact, doing so would be impractical and misleading. As such, all the above measures may play a part, though they operate within different dimensions of the implementation pursuit, which can broadly be categorised as the procedural and institutional elements and protective measures. One general feature is that implementation measures are precautionary if they help to shift the focus from reactive to proactive environmental management, in line with the rationale of the principle.

The analysis in this study is conducted against the background of this ongoing uncertainty as to the precise meaning of implementing precaution. To account for the various interpretations, this study presupposes that all three dimensions play a role in implementing precaution. Therefore, the analysis in Part III of this study incorporates all these dimensions. This will, it is hoped, provide the most complete picture of whether, and if so in what manner, precaution is implemented by the International Seabed Authority and what lessons can be learned for the future management of commercial seabed mining in the Area.

The following sections discuss some of the key issues in relation to implementing the three dimensions of the precautionary principle for the purpose of identifying criteria to evaluate whether the precautionary principle is being implemented. Section 2.5 then compiles these criteria to establish a framework for analysing the implementation of precaution.

\subsubsection{The Role of Values}

Those who demand regulatory decisions based on sound science are in fact promoting an ideology, which represents political decisions as "science".123

The first issue relevant to the institutional and procedural dimension of precaution is the role of subjective values. While scientific knowledge must be the

\footnotetext{
122 Sands and Peel (n. 21), page 218; Cooney and Dickson (n. 75), page 289.

123 Les Levidow and Susan Carr, 'Sound Science or Ideology?' (2000) 15 Forum for Applied Research and Public Policy 44-49, page 49.
} 
basis for environmental management decisions wherever possible, its advisory function is limited. ${ }^{124}$ Marine scientific research and environmental impact assessments are crucial for minimising uncertainties, yet some uncertainties will remain, especially when dealing with complex systems and pioneering activities. ${ }^{125}$ The precautionary approach recognises that decisions have to be made even in the face of uncertainties. Moreover, particularly in the context of sustainable development, decisions are characterised by the dynamic interdependence between nature and society. ${ }^{126}$ As discussed in Section 2.3.3, in order to identify protective measures that are effective, as required by the precautionary principle, we need to first establish the desired level of protection. This, in turn, ultimately depends on the values we place on both the biological and the mineral resources. What levels of harm to our global commons do we regard as acceptable? How do we want to source minerals for our hi-technology economies? How many resources do we want to preserve for our children's children? Do we want to preserve ecosystem viability, individual species, or individual creatures?

Given this value-component, deciding on precautionary measures comprises three considerations: scientific knowledge (what are the known facts?), uncertainties (where is the limit of our knowledge, can it be extended, and which assumptions are made?), and value considerations (how safe do we want to play?). It is important to clearly distinguish these considerations so as not to mistake value judgments for factual information. This is where Peel's focus on uncertainties, participation, and transparency, addressed individually in the following sections, becomes relevant. ${ }^{127}$

\subsubsection{Making Uncertainties Explicit}

Making uncertainties explicit and closely examining them enables administrative bodies to determine where objective information ends and moral or political considerations begin. Moreover, it informs value-based decisions.

124 Levidow and Carr (n. 123); Vern R. Walker, 'The Myth of Science as a Neutral Arbiter for Triggering Precautions' (2003) 26 Boston College International and Comparative Law Review 197-228; Mee (n. 54), page 119; Steinar Andresen, Lars Wallloe, and Kristin Rosendal, 'The Precautionary Principle: Knowledge Counts but Power Decides?' in Rosie Cooney and Barney Dickson (eds), Biodiversity and the Precautionary Principle: Risk, Uncertainty and Practice in Conservation and Sustainable Use (Earthscan, 2005) 39-54.

125 Chapter 2.4.4.

126 Karin Bäckstrand, 'Civic Science for Sustainability: Reframing the Role of Experts, PolicyMakers and Citizens in Environmental Governance' (2003) 3 Global Environmental Politics 24-41, page 36 .

127 Peel (n. 6), pages 156-159; Chapter 2.4.1. 
Quantifiable financial aspects of mineral mining can easily overshadow less direct environmental costs and benefits. Dollar bills in one's pocket may be more visible than breathing clean air and drinking fresh water. Yet, we have to take a step back and undertake a more comprehensive assessment. Critically examining uncertainties, including identifying 'areas of lack of knowledge, the unavailability of long-term data, untested methods, a one-sided presentation of evidence or a failure to highlight the limitations of studies' ${ }^{\prime 28}$ can provide the nuanced information necessary for a more complete weighing of costs and benefits.

\subsubsection{Participation}

Establishing expert advisory bodies is an institutional tool to provide best scientific information and identify uncertainties. However, once the limitations of the relevant scientific knowledge have been established, value considerations come into play. This is where any exclusive competence of expert bodies becomes disproportionate and questions of broader participation arise. ${ }^{129}$ As members of the public, the value-based viewpoints of experts must be taken into account, yet they are only one group within a heterogeneous society. ${ }^{130}$ Wide participation in the decision-making process is an important element of implementing precaution ${ }^{131}$ as it allows administrative bodies to capture the various concerns and viewpoints on perceptions of risk and acceptability ${ }^{132}$ Achieving public participation can involve the media, open discussion events, and stakeholder surveys but also institutionalised measures, such as an Ombudsperson or an advisory board representing NGOs and other stakeholders.

Public participation is all the more important for the International Seabed Authority, which is obliged to act on behalf of humankind. ${ }^{133}$ Yet, it is already a

\footnotetext{
128 Ibid., page 223 .

129 Jaye Ellis, 'Overexploitation of a Valuable Resource? New Literature on the Precautionary Principle' (2006) 17 European Journal of International Law 445-462, pages 450-451.

130 For detailed discussions about the role of experts, see Monika Ambrus et al. (eds), The Role of 'Experts' in International and European Decision-Making Processes: Advisors, Decision Makers or Irrelevant Actors? (Cambridge University Press, 2014).

131 Joyeeta Gupta, 'Glocalization: The Precautionary Principle and Public Participation' in David Freestone and Ellen Hey (eds), The Precautionary Principle and International Law: the Challenge of Implementation (Kluwer Law International, 1996) 231-246, page 246.

132 David Vanderzwaag, 'The Precautionary Principle and Marine Environmental Protection: Slippery Shores, Rough Seas, and Rising Normative Tides' (April 2002) 33 Ocean Development \& International Law 165-188, page 175 .

133 LOSC, article $137(2)$.
} 
challenge to provide a platform for the voices of interested scientists and concerned NGOs. To add to the difficulty, public awareness of the debates around seabed mining and even of the existence of the International Seabed Authority is currently minimal to non-existent. ${ }^{134}$ Chapter 7.4 discusses the challenges and potential solutions presented by this situation.

\subsubsection{Transparency}

Finally, transparency in the decision-making process provides accountability over how all three considerations, scientific knowledge, uncertainties, and value judgments, are taken into account when deciding over precautionary measures. As Peel points out: '[i]nsisting upon transparency in the process by which these decisions are reached provides some safeguard against the possibility that the values of the decision-maker will have an undue influence upon the decision-making process, rather than those that have a greater measure of community support.'135 Institutional transparency measures include publication of minutes and working documents as well as open meetings to allow NGOs and other stakeholders to observe meetings or, as in the case of meetings under the Convention on Biological Diversity, ${ }^{136}$ the United Nations Framework Convention on Climate Change, ${ }^{137}$ and the Desertification Convention, ${ }^{138}$ to address the meeting. ${ }^{139}$ In addition, procedural measures can aid transparency, for example through the publication of assessment criteria to enable external actors to retrace decisions. ${ }^{140}$ Similarly, 'science policies', that is 'decision rules about the way in which risk assessment scientists should proceed when they encounter specified types of uncertainties,' can aid transparency.141 Walker provides an example:

134 Kimone Thompson, Seabed Authority sg Laments Lack of Awareness about Entity (Jamaica Observer, 26 July 2013) <http://www.jamaicaobserver.com/news/Seabed-Authority-SGlaments-lack-of-awareness-about-entity>.

135 Peel (n. 6), page 225 .

136 See n. 17 .

137 See n. 18 .

138 United Nations Convention to Combat Desertification in Countries Experiencing Serious Drought and/or Desertification, Particularly in Africa (adopted 14 October 1994, entered into force 26 December 1996) 1954 UNTS 3.

139 For a discussion on public participation rules for various multilateral environmental agreements, see Glenn M. Wiser, 'Transparency in 21st Century Fisheries Management: Options for Public Participation to Enhance Conservation and Management of International Fish Stocks' (2001) 4Journal of International Wildlife Law and Policy 95-129, pages 114-118.

140 Peel (n. 6), page 225.

141 Walker (n. 124), page 214. 
[...] if no data are available for the rate of dermal absorption of a particular chemical, then scientists might agree on a plausible range of dermal absorption values, but might lack the data to narrow that range further. A science policy might then prescribe which of those plausible default values to assume (e.g., a particular default value for the rate of dermal absorption in adults)..$^{42}$

This approach can allow expert bodies to conduct risk assessment and make decisions over risk management in a principled way, taking into account value decisions reached by political bodies, ideally in close consultation with external stakeholders.

\subsubsection{A Normative Framework}

Administrative bodies faced with identifying value judgments can be aided by overarching normative frameworks. ${ }^{143}$ For the International Seabed Authority, the concept of common heritage of humankind is undoubtedly the most central normative framework. As discussed in Chapter 3.2, the common heritage concept sets the foundation for the legal regime for seabed mining in the Area. The ISA is specifically required to regulate and control seabed mining in accordance with the principle and 'on behalf of mankind as a whole.' 144 So what general guidance can that concept provide?

One the one hand, a central aim of the common heritage concept is to ensure intra-generational equity and sharing of the benefits of seabed mining. ${ }^{145}$ On the other hand, the concept includes what Kiss describes as the 'optimum use of resources in a spirit of conservation for future generations.' ${ }^{146}$ This

\footnotetext{
142 Ibid.

143 Peel (n. 6), page 224.

144 LOSC, article 153(1); see also articles 136, 137(2).

145 LosC, article 140; Jutta Brunnée, 'Common Areas, Common Heritage, and Common Concern' in Daniel Bodansky and others (eds), The Oxford Handbook of International Environmental Law (Oxford University Press, 2007) 551-573, page 561; Alexandre Kiss, 'The Common Heritage of Mankind: Utopia or Reality?' (1985) 40 International Journal 423-441, page 438.

146 Kiss (n. 145), page 438. See also C.C. Joyner, Legal Implications of the Concept of the Common Heritage of Mankind (1985) 35 International and Comparative Law Quarterly 190-199, page 195; Barbara Ellen Heim, 'Exploring the Last Frontiers for Minerals Resources: A Comparison International Law Regarding the Deep Seabed, Outer Space, and Antarctica' (1991) 23 Vanderbilt Journal of Transnational Law 819-849, page 827; Jennifer Frakes, 'The Common Heritage of Mankind Principle and the Deep Seabed, Outer Space,
} 
conservation and intergenerational element is central to the broader ambition of sustainable development. ${ }^{147}$

Guidance on the interplay of both ambitions of the common heritage concept can be drawn from the Advisory Opinion on the Responsibilities and Obligations of States Sponsoring Persons and Entities with Respect to Activities in the Area (SDC Advisory Opinion). ${ }^{148}$ When addressing the question whether states that sponsor mining operators may carry different responsibilities and potential liability in case of environmental harm, the Chamber linked its response to the common heritage principle. The Chamber recognised the LOSC provisions for preferential treatment of developing states designed to give effect to the economic dimension of common heritage. ${ }^{149}$ However, the Chamber confirmed that the paramount importance of the marine environment for humanity transcends the economic differences of states. As such, the responsibilities and liability of sponsoring states apply equally to all states, whether developing or developed. ${ }^{150}$ To find otherwise 'would jeopardize uniform application of the highest standards of protection of the marine environment, the safe development of activities in the Area and protection of the common heritage of mankind.'151

The SDC Advisory Opinion is further discussed in Chapters 3.6.2 and 4.3.3. For present purposes, it suffices to say that the Chamber, although recognising that socio-economic considerations play a role, aimed to convey that they should not compromise environmental protection efforts. Consequently, guidance from the normative framework of the common heritage concept includes a focus on environmental protection and safety standards. Moreover, as French puts it, the Chamber has done much to present the common heritage as 'very much an active principle of international law, as well as being a fundamental,

and Antarctica: Will Developed and Developing Nations Reach a Compromise?' (2003) 21 Wisconsin International Law Journal 409-434, page 413.

147 Nico Schrijver, Sovereignty over Natural Resources: Balancing Rights and Duties (Cambridge University Press, 2008) page 254; Rüdiger Wolfrum, 'Common Heritage of Mankind' in Max Planck Encyclopedia of Public International Law (2009), paragraphs 22-23; Kemal Baslar, The Concept of the Common Heritage of Mankind in International Law (Martinus Nijhoff, 1998), pages 103-105.

148 Responsibilities and Obligations of States Sponsoring Persons and Entities with Respect to Activities in the Area (Advisory Opinion) (Seabed Disputes Chamber, Case No. 17, 1 February 2011).

149 SDC Advisory Opinion, paragraphs 151-157.

$150 \quad$ Ibid., paragraph 158.

$15^{1}$ Ibid., paragraph 159. 
if a discrete, element of the promotion of global sustainable development,',152 which could itself be regarded as a normative framework. ${ }^{153}$

How we regulate the risks of seabed mining reveals what we value. ${ }^{154}$ Admittedly, humans do not have the best track record in making sustainable decisions. For seabed mining, we have tasked an international organisation with reaching good decisions, based on the best scientific knowledge available. However, subjective considerations are inevitable. Thus, we need to ensure participatory and transparent decision-making and begin by determining the desired environmental conservation objective. With its attention on intergenerational equity and high environmental standards, the common heritage concept offers some normative guidance in these pursuits.

\subsubsection{The Burden of Proof}

A further concern, affecting the procedural dimension of implementing precaution, is the controversial question of whether the precautionary approach warrants a reversal of the burden of proof. The traditional rationale, of allowing commercial and industrial-scale activities unless and until they can be proven to cause environmental harm, has allowed long-term ecological degradation. ${ }^{155}$ The precautionary approach is designed to put an end to this. It advocates against the idea of waiting for scientific proof. However, this does not always lead to a reversal of the burden of proof, as highlighted in the Pulp Mills case. ${ }^{156}$ Trouwborst demonstrates that under general international law such a reversal is not automatically part of the precautionary principle, ${ }^{157}$ although numerous cases exist in which the burden has specifically been reversed. ${ }^{158}$

$15^{2}$ Duncan French, 'From the Depths: Rich Pickings of Principles of Sustainable Development and General International Law on the Ocean Floor-the Seabed Disputes Chamber's 2011 Advisory Opinion' (2011) 26 The International Journal of Marine and Coastal Law 525-568, page 567.

153 UN Doc A/Res/66/288 (n. 25), annex paragraph 1.

154 The sentence is borrowed from Andre Nollkaemper, "What you risk reveals what you value", and Other Dilemmas Encountered in the Legal Assaults on Risks' in David Freestone and Ellen Hey (eds) The Precautionary Principle and International Law: the Challenge of Implementation (Kluwer Law International, 1996) 73-94.

155 Trouwborst (n. 52), page 195.

${ }_{15} 6$ Pulp Mills on the River Uruguay (Argentina v. Uruguay) (Judgment) [2010] ICJ Rep 71, paragraphs 162-164; see also Alan Boyle, 'The Environmental Jurisprudence of the International Tribunal for the Law of the Sea' (2007) 22 The International Journal of Marine and Coastal Law 369-381, pages 374-375.

157 Trouwborst (n. $5^{2}$ ), pages $222-227$.

158 Ibid., pages 201-219. 
However, the precautionary approach does affect the standard of proof, regardless of who bears the burden. In other words, even if the burden of proof is not reversed, opponents of a potentially harmful activity no longer have to provide conclusive proof of harmfulness. Instead the precautionary thresholds of, for example, threats of serious or irreversible damage apply. Thus, 'the precautionary principle has lowered the standard of proof.'159 Conversely, in cases where the burden of proof has been reversed, an agent of a potentially harmful activity would not have to prove absolute harmlessness either. ${ }^{160}$ After all, the presence of uncertainties prevents either side from producing conclusive evidence, be it to prove harmfulness or harmlessness. ${ }^{161}$ The objective of the burden of proof is not to determine the dangerous or benign nature of an activity but to demonstrate whether the thresholds for the precautionary principle are met. If they are, environmental protection has to be favoured even if uncertainties remain. ${ }^{162}$

A clear distinction must be drawn between (1) the general burden of proof in the context of a risky activity and (2) the reversal of the burden of proof as a specific implementation measure. Each of these are discussed separately below.

\subsubsection{Considerations for a General Allocation of the Burden of Proof}

Reversing the burden of proof is not a general requirement under the precautionary principle. However, it may play a role in specific circumstances. In order to analyse why and when a reversal might be appropriate, and when it might not be, it is necessary to examine the rationale behind a reversal of the burden of proof.

Applying the traditional burden of proof can render the precautionary approach ineffective and indeed inequitable. Consider a typical case, in which a local community is protesting against a corporation's plan to build an industrial plant, which could compromise water quality in the adjacent river on which the community depends. Even when applying the precautionary approach, the community is still left to prove threats of significant environmental harm. In this scenario, a lack of resources and expertise in the local community may hinder the effective application of the precautionary approach, rendering it meaningless. Moreover, in contrast to the corporation, the community might

\footnotetext{
159 Trouwborst (n. 8), page 192; See also: Freestone and Hey (n. 10); Peel (n. 6), page 155.

$160 \quad$ Trouwborst (n. 52), pages 225-226.

161 Peel (n. 6), page 155 .

162 Trouwborst (n. 8), page 187.
} 
not possess detailed information about the project, making it inequitable to place the burden of proof on the community. ${ }^{163}$

This is, however, a one way logic, since strictly reversing the burden of proof can also lead to inequalities. As Cooney notes, 'asking indigenous or local communities to demonstrate that their use of non-wood forest products, sea turtle eggs or pasture was not causing any harm would be tantamount to ending the livelihood activities of substantial proportions of the world's rural poor.'164

Consequentially, the underlying rationale of reversing the burden of proof is to ensure precaution works effectively and that a pinch of equity is added to the equation. As such, in deciding who to burden, it is important to consider who proposes an activity, who benefits from it, who bears the environmental costs, and who has access to information and resources. ${ }^{165}$ Chapter 7.5 demonstrates that the allocation of the burden of proof does not have to be a dichotomy. Both in the context of the International Seabed Authority, and indeed in some fisheries regimes, the question of the burden of proof is addressed in a nuanced way.

\subsubsection{Reversing the Burden of Proof as an Implementation Measure}

Despite not being an inherent element of the precautionary approach, reversing the burden of proof is nevertheless an important implementation measure. ${ }^{166}$ It has been applied to large-scale pelagic drift-net fishing, which is prohibited unless effective conservation and management measures can be taken to prevent 'unacceptable impact' of such fishing practices. ${ }^{167}$ Similarly, the European Court of Justice decided that cockle fishing in the Wadden Sea must be prohibited 'if it cannot be excluded, on the basis of objective information, that [cockle fishing] will have a significant effect on [a particular] site, either individually or in combination with other plans or projects. ${ }^{\prime 68}$ The bur-

\footnotetext{
163 Cooney (n. 70), page 234; Request for an Examination of the Situation in Accordance with Paragraph 63 of the Court's Judgment of 20 December 1974 in the Nuclear Tests (New Zealand v. France) Case [1995] ICJ Rep 1995 (Dissenting Opinion of Judge Weeramantry), page 342.

164 Cooney (n. 70), page 234.

165 Cooney and Dickson (n. 76), page 303.

166 Trouwborst (n. 52), page 223.

167 UNGA, UN Doc A/44/225 (22 December 1989), paragraph 4.

168 Landelijke Vereniging tot Behoud van de Waddenzee and Nederlandse Vereniging tot Bescherming van Vogels $v$ Staatssecretaris van Landbouw, Natuurbeheer en Visserij (C-127/02) [2004] ECR I-7405, paragraphs 44-45, 59, 67; see also Elen R. Stokes, 'Liberalising the Threshold of Precaution-Cockle Fishing, the Habitats Directive, and Evidende of a New Understanding of "Scientific Uncertainty"' (2005) 7 Environmental Law Review 206-214.
} 
den of proof was also reversed for bottom fishing in certain areas with seamounts, hydrothermal vents, cold-water corals, and sponge fields managed by the South Pacific Regional Fisheries Management Organisation. ${ }^{169}$ Similarly, a reversed burden of proof could be applied in marine protected areas beyond national jurisdiction. ${ }^{170}$ As these examples show, while it is not an automatic element of precaution, reversing the onus of proof for selective sites or activities can be a means to implement the precautionary approach.

What has become clear is that no generic solutions exist. In some cases reversing the burden of proof may be a necessary precautionary measure, in other cases it may render the precautionary approach ineffective or inequitable and alternatives are more appropriate. Either way, potential counter-effects must be considered. Again, the desired outcome should be net environmental protection. Chapter 7.5 of this study assesses whether the burden of proof is or indeed could even be reversed in the specific context of the International Seabed Authority, bearing in mind the overarching aims of ensuring effectiveness and equity.

\subsubsection{The Nature of Uncertainties}

A further aspect, affecting primarily the procedural dimension of implementing precaution, is the need to consider the type of uncertainties at hand. Explicitly examining the uncertainties involved in environmental risks is an important aspect of the precautionary approach.

Epistemic uncertainties arise due to the imperfection of our knowledge, deriving from inadequate or incomplete data, sampling errors or measurement biases, and can in principle be overcome through further rigorous research. ${ }^{171}$ In contrast, uncertainties can also be of an ontological nature, meaning that the system being studied is intrinsically complex and variable. ${ }^{172}$ Marine biodiversity and deep ocean ecosystems fall within this latter category. ${ }^{173}$ These uncertainties are not temporary and go beyond strictly scientific uncertainties. ${ }^{174}$

\footnotetext{
169 SPRFmo, 'Conservation and Management Measure for the Management of Bottom Fishing in the SPRFMO Convention Area' (смM 4.03, 29 April 2016) <https://www.sprfmo .int/assets/Fisheries/Conservation-and-Management-Measures/CMM-4.03-BottomFishing-2016-4Mar2016.pdf>, paragraph 22.

$170 \quad$ UN Doc A/61/65 (n. 93), annex I paragraph 61.

171 Walker et al. (n. 71), page 13; Cooney (n. 70), page 229.

172 Ibid., pages 13-14.

173 Cooney (n. 70), page 229.

174 S.R. Dovers and J.W. Handmer, 'Ignorance, the Precautionary Principle, and Sustainability' (1995) 24 Ambio 92-97; Cooney (n. 70), page 229.
} 
When applying precaution to seabed mining, both types of uncertainties are relevant. Some of the challenges of regulating mining activities derive from the fact that the mining technology is untested and will be deployed in (quite literally) unchartered waters. The uncertainties associated with faults in pioneering technology will most likely reduce with time. However, ontological uncertainties relating to the marine environment and its biodiversity will persist. Consequently, it is all the more important for the International Seabed Authority to examine fully the uncertainties and to implement the precautionary approach.

\subsubsection{Dealing with Uncertainty in Complex Systems: Adaptive Management}

Directly linked to the presence of uncertainties and the nature of complex systems is the option of adaptive management. Relatively strict precautionary responses, such as reversing the burden of proof, might be appropriate for particularly vulnerable ecosystems or for activities potentially causing irreversible harm. On the other end of the scale of precautionary responses, adaptive management may be an option for less serious situations.

Instead of being paralyzed by conservation aims, one way to address uncertainties is to design environmental management as scientific experiments, the findings of which then influence decision-making. This so-called adaptive management deserves close attention, not least because it is a way to build precaution into the regulatory framework and can be particularly suitable for biodiversity management ${ }^{175}$ and complex systems in general. ${ }^{176}$

The core idea is to make small interventions, which do not cause irreversible harm, to generate further knowledge about the resource. This knowledge is then used to re-assess whether activities can continue or not and which management option are most appropriate. As Cooney summarises, 'adaptive management involves management actions that are designed as experiments to produce information about the resource being managed. It emphasizes making modest, reversible management interventions, careful

175 CBD COP07,Decision VII/12, UNEP/CBD/COP/DEC/VII/12 (13 April 2004), paragraphs 10-12; Cooney (n. 7o), pages 238-239; Brendan Moyle, 'Making the Precautionary Principle Work for Biodiversity: Avoiding Perverse Outcomes in Decision-Making Under Uncertainty' in Rosie Cooney and Barney Dickson (eds), Biodiversity and the Precautionary Principle: Risk, Uncertainty and Practice in Conservation and Sustainable Use (Earthscan, 2005) 159-172, pages 170-172.

176 David A. Keith et al. 'Uncertainty and Adaptive Management for Biodiversity Conservation' (2011) 144 Biological Conservation 1175-1178, page 1178. 
monitoring of impacts and continual assessment and refinement of management practice as information increases. ${ }^{\prime 177}$ As such, adaptive management is a way to integrate ongoing scientific research with precautionary and reflective decision-making and includes four elements: ${ }^{178}$

(a) Monitoring the impacts of a management option based on agreed indicators;

(b) Promoting scientific research;

(c) Periodic evaluation of management options and feeding information back into the decision-making process; and

(d) Effective compliance mechanisms.

The relationship between adaptive management and the precautionary approach can be ambiguous. Some may regard it as an alternative to precaution, at least when the latter is interpreted in absolute terms as requiring widespread moratoria. Yet, in the fisheries context, adaptive management is seen as contributing to a precautionary approach, not least because the underlying aim is sustainable utilisation rather than pure conservation. ${ }^{179}$ For example, the Inter-American Tropical Tuna Association applies both a precautionary approach and adaptive management when assessing the impacts of expanded fisheries on stocks. ${ }^{180}$

Moreover, where despite uncertainties there are 'calls for moving in the dark, rather than sitting still, ${ }^{181}$ dynamic precautionary measures are beneficial. After all, any decision might later prove to be inadequate and revisiting them is an integral condition of the precautionary approach. ${ }^{182}$ The important point is to err on the side of caution. In this context, adaptive management can be appropriate where: (a) inaction itself is risky; (b) inaction is impractical for socio-economic reasons; or (c) the main danger is the cumulative impact of small but irreversible actions. ${ }^{183}$ In more concrete terms, the latter describes

177 Cooney (n. 70), page 238.

178 Cooney and Dickson (n. 76), page 304 .

179 Cooney (n. 116), page 31; Trevor Ward et al., Policy Proposals and Operational Guidance for Ecosystem-Based Management of Marine Capture Fisheries (wwF Australia, 2002).

180 Paul de Bruyn, Hilario Murua, and Martín Aranda, 'The Precautionary Approach to Fisheries Management: How This Is Taken into Account by Tuna Regional Fisheries Management Organisations (RFMOs)' (2012) 38 Marine Policy 397-406, page 399.

181 Holly Doremus, 'Precaution, Science, and Learning While Doing in Natural Resource Management' (2007) 82 Washington Law Review 547-579, page 554.

182 Ibid., page 553 .

183 Ibid., pages $555^{-557}$. 
the situation that nodule mining inevitably destroys life at the mine site, yet it is the cumulative impact of numerous mine sites, and other activities, that might critically endanger deep sea biodiversity. In sum, adaptive management:

is particularly useful in the implementation of the Precautionary Principle as it does not necessarily require having a high level of certainty about the impact of management measures before taking action, but involves taking such measures in the face of uncertainty, as part of a rigorously planned and controlled trial, with careful monitoring and periodic review to provide feedback, and amendment of decisions in the light of new information. ${ }^{184}$

Nonetheless, caution is warranted as adaptive management can be unsuitable in several circumstances. First, some mistakes are to be expected, making it unsuitable for activities that can quickly cause very serious or irreversible harm. ${ }^{185}$ In preventing invasive alien species, for instance, a small quantity of creatures can cause major and irreversible environmental damage. ${ }^{186}$ This analogy is relevant when considering management options for species at hydrothermal vents and seamounts many of which appear to be endemic and could thus be threatened by single mining operations. ${ }^{187}$ Rabinovich suggests that adaptive management is an effective way to ensure precautionary management of wildlife, except where the species are endangered or play a crucial role in a complex, poorly understood ecological situation. ${ }^{188}$

Second, adaptive management is not suitable for activities for which impacts must be measured on long-term scales. Where information about the environmental impacts of an intervention only becomes available several years after the intervention, an effective feedback mechanism may not be possible. Again,

184 Cooney and Dickson (n. 76), pages 304-305.

185 R. Cooney and Andrew T.F. Lang, 'Taking Uncertainty Seriously: Adaptive Governance and International Trade' (2007) 18 European Journal of International Law 523-551, pages $536-537$.

186 Cooney and Dickson (n. 75), page 298; Tim Low, 'Preventing Alien Invasions: The Precautionary Principle in Practice in Weed Risk Assessment in Australia' in Rosie Cooney and Barney Dickson (eds), Biodiversity and the Precautionary Principle: Risk, Uncertainty and Practice in Conservation and Sustainable Use (Earthscan, 2005) 141-156.

187 C.L. Van Dover et al., Environmental Management of Deep-Sea Chemosynthetic Ecosystems: Justification of and Considerations for a Spatially-Based Approach (ISA Technical Study: No. 9, 2011), pages 2, 45 .

188 Rabinovich (n. 75), page 186. 
this may be relevant for the deep seabed mining context as recovery rates of fauna may be particularly slow. ${ }^{189}$

Third, adaptive management can be misused in an attempt to postpone protective measures, in effect preventing more rigorous precautionary actions. This is particularly relevant in light of the danger of a relatively speedy transition towards exploitation contracts, which would then be difficult to modify. 190 Similarly, there is a risk of a degree of complacency once exploitation has been allowed. ${ }^{191}$ In sum, 'used indiscriminately or inappropriately, adaptive management mechanisms can operate to water down regulatory requirements, reduce public scrutiny of planning and development approval processes and accord preferential treatment to favoured industries, thus substantially detracting from any precautionary role they might serve in addressing uncertainty.'192

Avoiding these pitfalls requires a robust institutional design and independent decision-making bodies, able to halt or scale-down operations even against the wish of contractors, if necessary. The difficulties of such flexibility in the context of the International Seabed Authority are discussed in Chapter 7.3. Moreover, given that adaptive management directly responds to uncertainties, it requires transparent and participatory decision-making that clearly identifies value-based elements. ${ }^{193}$

In sum, prior to adaptive management being considered, it must first be assessed whether more rigorous precautionary measures are necessary and whether the procedural and institutional design allows for an effective and continuous adaptation of the management of seabed mining. Only if these criteria are considered can adaptive management support the precautionary approach.

\subsubsection{Examining Counter-Effects: the Aim of Net Environmental Protection}

A further important consideration will affect the procedural dimension and protective measures required to implement precaution. As set out in Chapter 1, the environmental risks of seabed mining include dangers to marine

189 See e.g. Christian Borowski and Hjalmar Thiel, 'Deep-Sea Macrofaunal Impacts of a Large-Scale Physical Disturbance Experiment in the Southeast Pacific' (1998) 45 Deep Sea Research Part II 55-81; Adrian G. Glover and Craig R. Smith, 'The Deep-Sea Floor Ecosystem: Current Status and Prospects of Anthropogenic Change by the Year 2025' (2003) 30 Environmental Conservation 219-241.

190 Chapter $7 \cdot 3$.

191 Carl J. Walters, 'Is Adaptive Management Helping to Solve Fisheries Problems?' (2007) 36 Ambio: A Journal of the Human Environment 304-7.

192 Peel (n. 6), page 154; see also Sidney A. Shapiro and Robert L. Glicksman, Risk Regulation at Risk: Restoring a Pragmatic Approach (Stanford University Press, 2003), pages 167-173.

193 Cooney and Lang (n. 185), pages 538-539. 
biodiversity. One aspect of particular importance in the biodiversity context is the potential for unintended side- or counter-effects.

The precautionary approach was first articulated in an industrial context relating to hazardous substances. Applying precaution to the biodiversity realm is therefore a departure from its original focus and prompts an important distinction. The potential harm from a hazardous substance can be avoided by not using the substance. Damage to biodiversity levels, however, can be caused by indirect counter-effects of a number of management options. ${ }^{194}$ The choice is often not between a clearly precautionary and a risky option but instead between 'risk and risk.'195 For trade in endangered species, for example, the choice might be between regulating such trade and thereby accepting a certain level of killing, or banning any trade but facing the prospect of illegal hunting without quotas. ${ }^{196} \mathrm{~A}$ similar logic can be applied to seabed mining under the ISA regime.

First, any measure to reduce and manage the effects of seabed mining on marine biodiversity may trigger unintended, and to an extent unforeseeable, ecological or other environmental counter-effects, because of the inherent complexities of species interactions and ecosystems.

Second, management decisions by the ISA may trigger counter-effects of a political nature. If, for example, the ISA was to impose restrictions that effectively prevented seabed mining, there would be a risk of mining corporations and states finding ways to circumvent the multilateral regime and proceed with mining activities with potentially far lower environmental standards. ${ }^{197}$

The point remains: what is considered a precautionary measure depends on the context. ${ }^{198}$ The most restrictive measures are usually perceived to represent the highest degree of precaution. Yet, this 'equation is often made with little detailed examination of context and potential consequences.' ${ }^{199}$ On the other hand, competing economic interests in natural resources may actually serve as an incentive to protect these resources. ${ }^{200}$ Bioprospecting and seabed mining could be regarded as competing economic interests over resources

\footnotetext{
194 Moyle (n. 175), page 160.

195 Cooney and Dickson (n. 75), pages 294-295.

196 Rabinovich (n. 75), page 186.

197 At present we see the opposite occurring. Although the Us is not yet a party to the LOSC, the us company Lockheed Martin is actively engaging with the ISA through holding two exploration contracts through its UK subsidiary, sponsored by the UK.

198 Cooney (n. 70), page 236; Moyle (n. 175).

199 Cooney (n. 70), page 236.

200 Cooney (n. 116), page $32-34$.
} 
both occurring in the deep oceans. Ironically though, the economic potential of marine genetic resources may actually serve as an incentive to protect particularly sensitive ecosystems in the deep ocean from mining, if not for environmental reasons, at least for economic ones. ${ }^{201}$

By the same token, Moyle reminds us that precautionary measures to avoid environmental threats may actually offer conservation benefits. He argues that a focus on avoiding harm makes the precautionary principle extremely timid. "The fear of a loss dominates the choice of strategy. While some risk aversion is warranted-and this is especially the case in the presence of irreversibility - this timidity leads to foregone opportunities to improve conservation outcomes.'202 There is some truth in this. If the ISA strikes an adequate balance between utilisation and conservation, this could set a standard for other (future) ocean uses. The extensive competencies of the ISA, including its explicit mandate to act on behalf of humankind, ${ }^{203}$ have triggered high hopes.

What has become clear is that applying precaution requires thinking beyond the immediate effects of any management measure. The overall aim is net environmental protection. To this aim, the ISA must decide upon specific conservation objectives. In assessing the effectiveness of seemingly precautionary measures, long-term effects (both positive and negative) as well as possible counter-effects must be considered and options compared.

\subsubsection{Socio-Economic Considerations}

A last aspect that affects the protective measures adopted to give effect to the precautionary principle, is socio-economic considerations.

Principle 15 of the Rio Declaration requires measures to be cost-effective, which includes the costs associated with the threat materialising and the costs of precautionary measures to prevent it. ${ }^{204}$ Problematically, while a price tag can be put on the economic costs and profit of mineral mining, the direct benefits of intact ecosystems (let alone any intrinsic values) are difficult if not impossible to quantify. Moreover, in the context of seabed mining, current precautionary measures might not always generate actual costs, especially if the measures involve limiting or prohibiting mineral exploitation at particularly

\footnotetext{
201 For a discussion about the need for benefit sharing arrangements to provide conservation incentives, see Nele Matz, 'Marine Biological Resources: Some Reflections on Concepts for the Protection and Sustainable Use of Biological Resources in the Deep Sea' (2002) 2 Non-State Actors and International Law 279-300.

202 Moyle (n. 175), page 166.

203 Losc, article $137(2)$.

204 Trouwborst (n. 52), pages 230-232.
} 
vulnerable sites before it even starts. Some costs would be foregone business opportunities rather than actual expenses. Similarly, limiting mining at hydrothermal vents might in turn create potential future profit from commercialising research into chemosynthetic ecosystems. Additionally, the costs of repairing future environmental damage are difficult to quantify 'and the costs of irreversible harm are, by definition, inestimable. ${ }^{205}$ What becomes clear is that, as the European Commission notes, weighing precautionary measures 'cannot be reduced to an economic cost-benefit analysis', although such analysis may be part of the examination where appropriate. ${ }^{206}$

Beyond cost-benefit analyses, the question is whether the precautionary approach is interpreted as choosing the most cost-effective way towards environmental protection or whether precautionary measures are only required if they are cost-effective? The answer is self-evident. As Trouwborst stresses, the logic of the latter is flawed in the context of precaution as the very uncertainties to which precaution responds, as well as the irreversibility of some environmental harm, render a purely economic analysis impossible. ${ }^{207}$ Instead, the implementation criteria of effectiveness and proportionality already capture the essence that is to invest what is necessary to achieve the desired level of protection but not more. This is supported by the fact that numerous international instruments define precaution without any reference to costeffectiveness, ${ }^{208}$ and under customary international law there does not seem to be a separate requirement of cost-effectiveness. ${ }^{209}$ After all, the French version of the Rio Declaration refers to 'mesures effectives' with no separate mention of cost-effectiveness.

Additionally, socio-economic factors are inherent in any precautionary logic. The principle rests on the rationale that some restrictive measures today are cheaper than the collapse of fish stocks or the clean-up of major pollution tomorrow, ${ }^{210}$ not to mention 'the impossibility of repairing irreparable damage. ${ }^{211}$ The World Health Organisation reported that the threat of ecosys-

205 Trouwborst (n. 8), page 193.

206 Commission of the European Communities (n. 55), pages 18-19; Lucy Emerton et al. 'Economics, the Precautionary Principle and Natural Resource Management: Key Issues, Tools and Practices' in Rosie Cooney and Barney Dickson (eds), Biodiversity and the Precautionary Principle: Risk, Uncertainty and Practice in Conservation and Sustainable Use (Earthscan, 2005) 253-274; Trouwborst (n. 52), pages 249-253.

207 Trouwborst (n. $\left.5^{2}\right)$, pages $263^{-264}$.

208 Ibid., pages 259-261.

209 Ibid., page 280.

210 Ibid., page 239; Hey (n. 114), page 309-310; Freestone and Hey (n. 9), page 158.

211 Trouwborst (n. $5^{2}$ ), page 280. 
tem changes to human health 'indicates strongly that a precautionary approach to environmental protection is the most effective way to protect and enhance health.'212 In sum, not being precautionary might actually lead to an inefficient allocation of financial resources, 'particularly when alternative technologies and/or products are available.'213 As Trouwborst summarises: proportional and effective precautionary measures are assumed to be cost-effective. ${ }^{214}$

Moreover, in the long run, a stable economy is directly dependent on a healthy environment and sustainable management of natural resources. What underpins the principle is the realisation that using natural resources sustainably is not a luxurious option for the morally minded but a simple necessity if we want to maintain a world with liveable conditions and a healthy economy for generations to come. ${ }^{215}$ As such, socio-economic sustainability is built into the precautionary principle. ${ }^{216}$

Lastly, one of the critiques of precaution is that it may hamper economic growth and innovation. ${ }^{217}$ However, this ignores the fact that the demand for green technology is indeed a major driver of innovation. ${ }^{218}$ For seabed mining this has led to the development of impact-reducing mining technology, ${ }^{219}$ yet it could also influence innovation for using substitute metals and alternative metal supply, such as recycling electronic waste.

212 Carlos Corvalan, Simon Hales, and Anthony McMichael, Ecosystems and Human WellBeing: Health Synthesis. A Report of the Millenium Ecosystem Assessment (World Health Organisation, 2005), page 10.

213 Freestone and Hey (n. 10), page 12.

214 Trouwborst (n. 8), page 193.

215 Robert T. Watson and A.H. Zakri, Living Beyond Our Means: Natural Assets and Human Well Being (Statement from the Board of the Directors of the Millennium Ecosystem Assessment) (2005) <http://www.wri.org/sites/default/files/pdf/ma_board_final_statement.pdf >, page 5.

216 Trouwborst (n. 52), page 238.

217 Handl speaks of 'no-growth strands.' Günther Handl, 'Environmental Security and Global Change: The Challenge to International Law' in Winfried Lang and others (eds), Environmental protection and international law (Graham \& Trotman, 1991) 3-33, page 25.

218 Ram Nidumolu, C.K. Prahalad, and M.R. Rangaswami, 'Why Sustainability Is Now the Key Driver of Innovation' (2009) Harvard Business Review 1-10; Fostering Innovation for Green Growth (OECD Green Growth Studies, OECD Publishing, 2011) <http://www.oecd-ilibrary .org/science-and-technology/fostering-innovation-for-green-growth_9789264119925-en>.

219 An example is the Joint Industry Project "Towards Zero Impact" for deep sea mining. See Stanislav Verichev, Technologies for mining in the deep sea, presentation given the Workshop'FutureOcean-SeafloorMineralResources'inKiel,Germany(18-20March2013) $<$ http://fileserver.futureocean.org/forschung/r3/Verichev_technologies_for_mining deep_sea.pdf $>$. 


\subsection{Framework for Analysing the Implementation of Precaution: Assessment Criteria}

The discussion on the precautionary approach has revealed a plethora of issues involved in its implementation. First, while the precautionary logic is anything but new, its translation into a legal principle has caused us to re-examine many of the most basic concepts on environmental management policy'220 because its rationale is proactive environmental management. Indeed, its crucial feature is timing. It calls for early action in the face of threats of environmental harm, even when scientific uncertainties remain. To the frustration of many, the precautionary approach does not dictate specific measures. The reason is simple: ' $[\mathrm{i}] \mathrm{t}$ is not in the nature of any legal system to provide mathematically certain solutions to problems which may be presented to it; for so long as different factual circumstances can arise in multiple permutations, uncertainty cannot be eliminated from law.'221

Nonetheless, what can be developed from the rich discussions of the principle is a set of steps, an implementation cycle to operationalise the precautionary approach ${ }^{222}$ (see Figure 2). Importantly, these steps are both non-exhaustive and non-linear so their order and direction is merely a broad indication. Indeed, they can be understood as a checklist of the various elements that can be involved in implementing precaution and which have to be adapted to each individual context.

What emerges from the analysis in this chapter is that there are three interlinked dimensions involved in implementing precaution: procedural elements, institutional elements, and the adoption of protective measures. Each of the various steps indicated in Figure 2 affects at least two of these dimensions. For example, assessing environmental risks and identifying uncertainties is a procedural task which requires institutional capacity. Moreover, specific institutional designs, such as an expert advisory body, can facilitate this assessment. Other important procedural measures include environmental impact assessment, transparency, and capturing public values and opinions. However, implementing precaution does not stop there. The criterion of effectiveness calls for protective measures that are adequate for ensuring the desired level of environmental protection. Some measures typically associated with

220 Freestone and Hey (n. 9), page 268.

221 Andrew Clapham (ed), Brierly's Law of Nations: An Introduction to the Role of International Law in International Relations (Oxford University Press, 2012), page 84.

222 For a list of guidelines on how to apply the precautionary approach to biodiversity conservation, see Cooney and Dickson (n. 76). 


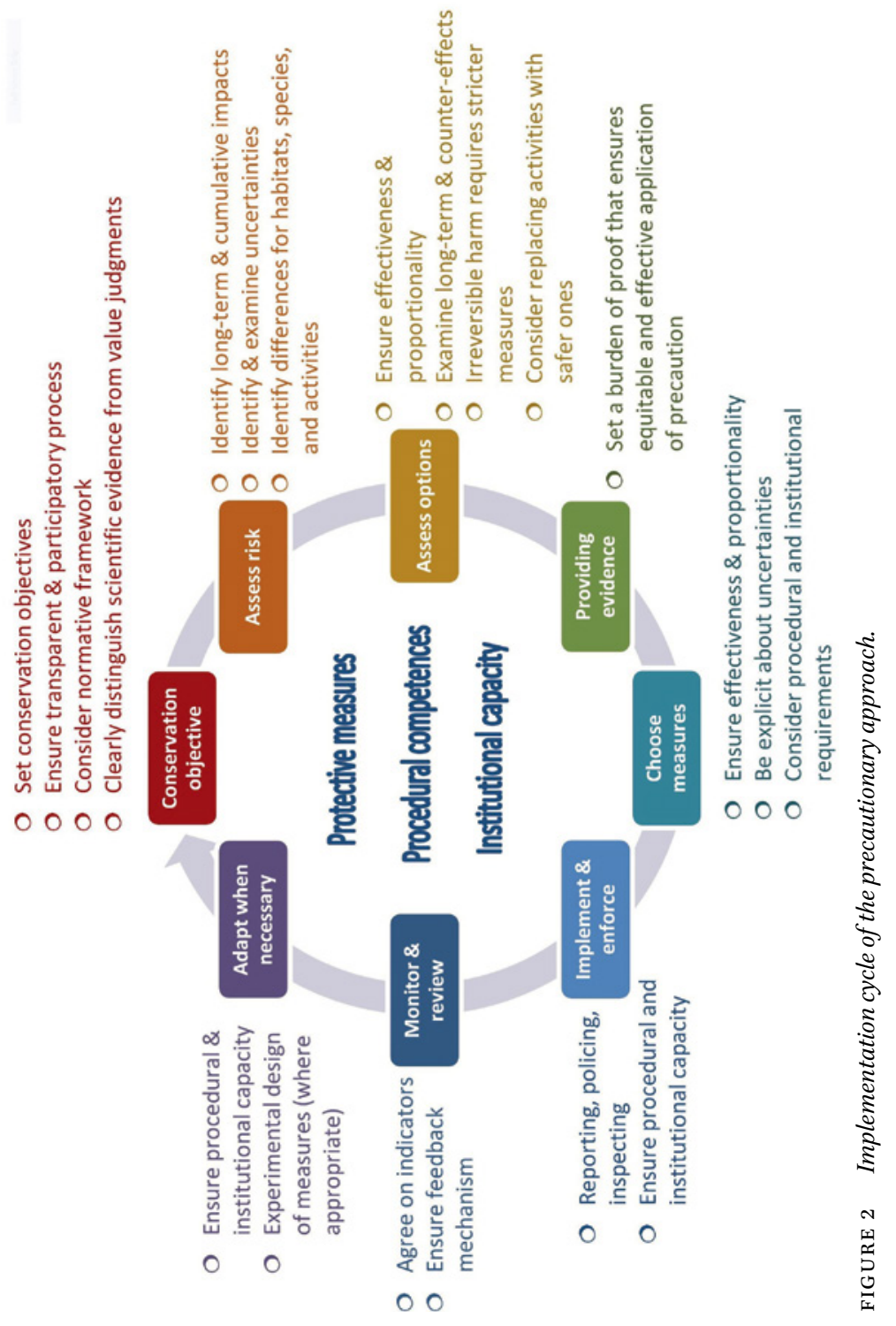


precaution are safety margins, scientific research to limit uncertainties, moratoria, or adaptive management. However, any measure can be precautionary if it meets the criteria of effectiveness and proportionality. Assessing the various options includes considering long-term and counter-effects, and opting for stricter measures where the relevant harm could be irreversible.

Gathering evidence to assess the risks (and potential benefits) of activities can also be achieved in various ways. Examples are reversing the burden of proof, adding evidentiary presumptions to the assessment, or using adaptive management, where appropriate, to design activities as experiments in order to collect data from them and feed it back into the risk assessment.

What has become clear is that precaution is closely linked with other principles stretching from prevention, ecosystem approach, environmental impact assessments, and protection and preservation of the marine environment, to equity, public participation, transparency, sustainable development, and the common heritage of humankind. While a discussion on the nature and individual status of these concepts is beyond the scope of this study, it is worth highlighting, as shown in this chapter, that their implementation is interwoven with the precautionary approach. What has also become evident is that for precaution, and indeed other principles, to contribute effectively to a re-design of marine governance beyond national jurisdiction, rigorous implementation is needed. ${ }^{223}$ This goes beyond a formal declaration of principles and requires institutional and procedural capacity. ${ }^{224}$

As for the precautionary principle, implementation requires a range of considerations as discussed above. Yet, the central question is when have we reached a level of measures which amounts to fulfilling the obligation to implement the precautionary approach? In other words, at what point does the sum of applied precautionary measures add up to the full principle? The answer, inconveniently, is as multifaceted as so much about the principle: it depends on the context. Even within one institution, the implementation may vary. Particularly vulnerable ecosystems require a different standard of precautionary measures than others. What is clear is that only fulfilling one aspect, such as transparent decision-making, cannot be enough. Again, direction is provided by the overall aim that is net environmental protection.

Against the background of this analysis, the steps identified in Figure 2 form the framework that is used in Part III of this study to evaluate whether, and if so in what manner and to what extent, the ISA is implementing the precau-

223 David Freestone, 'Problems of High Seas Governance' [2009] UNSW Faculty of Law Research Series 1-31, page 22.

224 Oude Elferink (n. 36), page 255. 
tionary principle. In order for the ISA to successfully implement precaution, it has to put in place the institutional structures and procedural framework to both design a strategic management plan for seabed mining that is capable of meeting agreed environmental conservation objectives and to interfere if there are risks of failing to meet these objectives. Moreover, the ISA has to adopt effective and proportionate environmental protection measures and continue to implement, monitor, and adapt these measures in line with changes in scientific knowledge and the interpretation of uncertainties. In doing so, the ISA has to address the individual issues listed next to each step in Figure 2, as appropriate.

Before moving to this implementation analysis, however, it is necessary to understand the mandate and institutional structure of the ISA. The following chapters in Part II of this study, thus examine the ISA's institutional framework, its competencies and, in particular, its environmental mandate to set the scene for the core analysis in Part III. 